\title{
CZECH PERSPECTIVE ON THE VALIDITY OF INTERNATIONAL ARBITRATION CLAUSES CONTAINED IN AN EXCHANGE OF EMAILS UNDER THE NEW YORK CONVENTION
}

\author{
PETR BŘÍZA*
}

\begin{abstract}
The article deals with the writing requirement of the arbitration clause under the New York Convention (the "Convention"). The discussion has been triggered by the recent Czech Supreme Court decision on the formal validity of an arbitration clause contained in an exchange of emails. The author first recalls the drafting history of the Convention and rationale behind the writing requirement. Then he analyses its interpretation in the practice of court before and after the 2006 UNCITRAL Recommendation, which suggested extending the interpretation to modern forms of communication such as email. The main part of the article closely scrutinizes the Czech Supreme Court's decision on the issue. The Court followed the 2006 Recommendation and the majority of its foreign counterparts. However, it also had to deal with the question of whether an email has to be accompanied by a qualified electronic signature for the written form to be met, as this is (unfortunately) the Court's requirement when it comes to relations governed by Czech law. Fortunately, the Court has taken an international approach looking both to foreign courts' practice and to its own case-law under other international conventions such as the CISG or the CMR. Thus it has arrived at the conclusion that the writing requirement under the Convention is met also in the case of an arbitration agreement contained in an exchange of simple emails.
\end{abstract}

Keywords: arbitration clause; New York Convention; written form; electronic legal act; arbitration proceedings

Klíčová slova: rozhodčí doložka; Newyorská úmluva; písemná forma; elektronické právní jednání; rozhoděí řízení

DOI: $10.14712 / 23366478.2020 .37$

\section{INTRODUCTION}

The 1958 New York Convention on Recognition and Enforcement of Foreign Arbitral Awards (hereinafter the "New York Convention" or the "Convention") 1 with its more than 160 contracting parties is one of the most successful conventions

\footnotetext{
* Senior lecturer at the Commercial Law Department of the Charles University Faculty of Law, arbitrator and founding partner of the law firm Bř́za \& Trubač.

1 Convention on the Recognition and Enforcement of Foreign Arbitral Awards, done in New York, 10 June 1958. UNTC. United Nations Treaty Collection. [online]. Accessed [April 11, 2020] at: https://treaties .un.org/Pages/ViewDetails.aspx?src=TREATY\&mtdsg_no $=$ XXII-1\&chapter=22\&clang=_en.
} 
in the field of private international law and is owed a lot by international commercial arbitration for its success. However, the more than 60-year-old text of the Convention faces new challenges, as the world around us is quickly evolving and changing. This is true particularly in the area of communication, where emails, Internet, social media, and other means of electronic communication have entirely revolutionized not only the speed at - but also in particular the forms in - which people communicate, transact, and do business in general.

In the era of the Convention's birth it was quite common for an arbitration agreement to be contained in an exchange of letters or telegrams. Nowadays, the younger generation often does not know what a "telegram" even is and most of everyday business is done via email/Internet, not via hard copy contracts or letters. However, the Convention requires written form for an arbitration agreement (clause) to be valid and the electronic communication of our times was not foreseen in the text of the Convention. This paper deals with the question of whether and how this problem has been overcome by interpretation and, in particular, how the Czech Supreme Court approached the issue in its recent decision, where the arbitration clause was contained in an exchange of emails without a qualified electronic signature. ${ }^{2}$

\section{LEGAL FRAMEWORK - NEW YORK CONVENTION'S FORM REQUIREMENT}

\subsection{THE RULE OF ART. II(2) OF THE CONVENTION}

The New York Convention defines an arbitration agreement or arbitral clause ${ }^{3}$ as "an agreement in writing under which the parties undertake to submit to arbitration all or any differences which have arisen or which may arise between them in respect of a defined legal relationship, whether contractual or not, concerning a subject matter capable of settlement by arbitration". ${ }^{4}$ The contracting States undertake to recognize such an agreement and their court, when faced with the arbitration agreement, "shall, at the request of one of the parties, refer the parties to arbitration, unless it finds that the said agreement is null and void, inoperative or incapable of being performed". 5

What is meant by "agreement in writing" is defined in Art. II(2) of the Convention, which, being crucial for our topic, reads as follows:

2 By "qualified electronic signature" is meant an electronic signature that is created by a qualified electronic signature creation device, and which is based on a qualified certificate for electronic signature or its equivalent. See, e.g., Regulation (EU) No 910/2014 of the European Parliament and of the Council of 23 July 2014 on electronic identification and trust services for electronic transactions in the internal market and repealing Directive 1999/93/EC. Official Journal of the European Union, L 257. 23. 7. 2014, Art. 3(12).

3 The author will use the term "arbitration agreement" even for the agreement contained in an arbitral clause (which is part of a contract), as the difference is not relevant in this paper.

4 See Art. II (1) of the Convention.

5 See Art. II (3) of the Convention. 
“The term 'agreement in writing' shall include an arbitral clause in a contract or an arbitration agreement, signed by the parties or contained in an exchange of letters or telegrams."

The question, discussed in more detail below, is whether this text should be construed to encompass also arbitration agreements contained in an exchange of emails without an electronic signature.

One last provision to be mentioned which might also assist in understanding the true purpose and the scope of the writing requirement is Art. IV(1)(b) of the Convention. It stipulates that in order to obtain the recognition of an arbitral award under the Convention, an applicant must provide "[t]he original agreement referred to in article II or a duly certified copy thereof"'.

\subsection{RATIONALE BEHIND THE WRITTEN-FORM REQUIREMENT}

To better understand the rule, we should first look at the reasons for the writing requirement. In general, at least in the civil law tradition, there are several reasons for the written form of a contract. First is the evidential function, in that the written form enables to better prove the content of the contract and thus does away with (or minimizes) disagreements over what was agreed and when. Second, the writing requirement often has much to do with a cautionary function, i.e., it puts the parties on notice. The fact that something has to be written down before it is binding enables parties to reflect upon their decision, it alerts them that something significant is taking place. ${ }^{6}$ Also, formalities might be required to mark the transition from negotiation to contract, so that the parties (including third parties) are clear on the moment at which the negotiations have reached the stage of consensus and legal obligation. Sometimes, and especially in consumer contracts, the primary purpose of the written-form requirement is to provide information. ${ }^{7}$

It is not entirely clear which of these reasons - and especially to what extent - was behind the writing requirement of Art. II, when the Convention was adopted. It seems that the goal was to exclude cases involving acceptance by performance, conduct, or tacit acceptance. ${ }^{8}$ This was also confirmed by the practice, as the courts generally ruled out oral arbitration agreements, even when it was confirmed by the other party (only) in writing or when there was a tacit acceptance or performance of the contract. ${ }^{9}$ The

6 Some authors distinguish between the cautionary and the channelling function, the latter meaning that the writing requirement "allows for certain types of agreement to be singled out as special legal mechanisms with particular attributes" or "[e]qually, it requires that particular transactions take a prescribed form, in order to attract specific legal consequences or characteristics". See LANDAU, T. - MOOLLAN, S. Article II and the Requirement of the Form. In: GAILLARD, E. - DI PIETRO, D. (eds.). Enforcement of Arbitration Agreements and International Arbitral Awards: The New York Convention 1958 in Practice. London: Cameron May Ltd, 2008, p. 220.

7 For details on all these written-form functions see KÖTZ, H. European Contract Law. 2nd Edition. Oxford University Press, 2017, p. 75-76. For a similar yet slightly different account of these functions see LANDAU, op. cit., pp. 219-221.

8 See LANDAU, op. cit., p. 190, footnote 5 and the vast literature cited therein.

9 United Nations, Commission on International Law. Article II (2) of the Convention on the Recognition an Enforcement of Foreign Arbitral Awards (New York, 1958). [online]. 14 December 2005. A/CN.9/WG.II 
courts' practice (though diverging) shows that the evidentiary function is usually at the forefront, in that it either proves the initial consent of the parties to arbitration, or proves (records) the exact terms of the arbitration agreement, thus bringing certainty to the ensuing arbitral process. ${ }^{10}$ The UNCITRAL Working Group on Arbitration summed it up in the following words: "[b]y requiring either a signature or an exchange of documents, the form requirement ensures that the parties' assent to arbitration is expressly recorded." 11 It follows that the writing requirement under the Convention should primarily serve an evidentiary and information purpose.

From this point of view there is no reason to interpret the circumstances (forms) described in $\operatorname{Art}$. II(2) of the Convention to be exhaustive. If the arbitration agreement is somehow recorded for future reference, it should suffice for the writing requirement to be met, provided there is either the signature of both parties or an exchange of communication between them, even though the given means of communication is not explicitly listed in the Convention. This is confirmed by the UNCITRAL recommendation of 2006, to which we now turn.

\subsection{THE UNCITRAL RECOMMENDATION REGARDING THE INTERPRETATION OF ART. II(2)}

There were several reasons behind UNCITRAL's adoption of the 2006 Recommendation regarding the interpretation of Art. II(2) of the Convention (the "Recommendation")..$^{12}$ First of all, there had been some diverging court practice and also some differences of expression between the five equally authentic texts of the Convention. ${ }^{13}$ Secondly, UNCITRAL had to react to the fact that the text of the Convention had been outgrown by advances in technology and the rise of electronic commerce.

Bearing in mind the rationale behind the writing requirement, the fast-evolving electronic commerce, other recent UNCITRAL instruments or their amendments ${ }^{14}$ and also domestic legislation of States, UNCITRAL proposed a subtle, yet very effective clarification of the Convention's text. It recommends that "article II, paragraph 2, of

/WP.139, p. 7-9. Accessed [April 11, 2020] at: https://undocs.org/en/A/CN.9/WG.II/WP.139. ("UNCITRAL 2005").

10 For more details see UNCITRAL 2005, supra note 9, paras. 12-23. See also United Nations. UNCITRAL Secretariat Guide on the Convention on the Recognition and Enforcement of Foreign Arbitral Awards. [online]. New York: United Nations Publications, 2016, 2016 Edition, pp. 51-57. Accessed [April 12, 2020] at: http://newyorkconvention1958.org/pdf/guide/2016_Guide_on_the_NY_Convention.pdf (the "NYC Guide").

11 See UNCITRAL 2005, supra note 9, at 6.

12 United Nations, General Assembly. Recommendation regarding the interpretation of article II, paragraph 2, and article VII, paragraph 1, of the Convention on the Recognition and Enforcement of Foreign Arbitral Awards, done in New York, 10 June 1958. Official Records of the General Assembly, Sixty-first Session, Supplement No. 17, 2006. A/61/17, paras. 177-81 and Annex II. [online]. Available at: www.uncitral.org /pdf/english/texts/arbitration/NY-conv/A2E.pdf (the "Recommendation").

13 English and Russian texts differ from French and Spanish. See in more detail LANDAU, op. cit., p. 245, or NYC Guide, supra note 10, at 56 n. 271.

14 The 1985 UNCITRAL Model Law on International Commercial Arbitration, as subsequently revised, particularly with respect to Article 7 (2006), the UNCITRAL Model Law on Electronic Commerce (1996), the UNCITRAL Model Law on Electronic Signatures (2001) and the United Nations Convention on the Use of Electronic Communications in International Contracts (2005). 
the Convention on the Recognition and Enforcement of Foreign Arbitral Awards, done in New York, 10 June 1958, be applied recognizing that the circumstances described therein are not exhaustive". Instead of enlarging the list of circumstances meeting the form requirement, UNCITRAL simply emphasized the fact that the list is not meant to be exhaustive, thus ensuring that any new communication that reflects the basic idea of the norm (guaranteeing a record of the agreement) ${ }^{15}$ will fit in the scope of the rule. One has to applaud this highly efficient way of achieving the desired purpose.

Despite it being ancillary to the main theme of this paper, it is still worth mentioning that the Recommendation also clarified the interpretation of Art. VII para. 1 of the Convention, which reads: "The provisions of the present Convention shall not [...] deprive any interested party of any right he may have to avail himself of an arbitral award in the manner and to the extent allowed by the law or the treaties of the country where such award is sought to be relied upon." UNCITRAL recommends that this provision "should be applied to allow any interested party to avail itself of rights it may have, under the law or treaties of the country where an arbitration agreement is sought to be relied upon, to seek recognition of the validity of such an arbitration agreement". ${ }^{16}$ This enables interested parties to rely on more favourable domestic provisions on the form requirement to uphold arbitration agreements even where the writing requirement set out in $\operatorname{Art}$. II(2) of the Convention would otherwise not be met. To give a specific example, if the domestic legislation (of the country where an arbitration agreement is sought to be relied upon) allows for an arbitration agreement to be concluded orally, an interested party may rely on it to uphold the validity of the agreement regardless the text of Art. II(2) of the Convention. UNCITRAL hopes that this "would allow the development of rules favouring the validity of arbitration agreements in a wider variety of situations". ${ }^{17}$ The truth is that many domestic laws allow for a more lenient form requirement than is stipulated in Art. II(2) of the Convention ${ }^{18}$ and thus the recommended interpretation may significantly buttress the formal validity of arbitration agreements within the scope of the New York Convention. ${ }^{19}$

\section{COURTS' INTERPRETATION OF THE RULE}

We will now take a brief look at the practice of national courts before and after the adoption of the Recommendation to suggest how other States courts (would) approach the question of formal validity of an arbitration agreement contained in exchange of emails without an electronic signature. The following is not a comprehensive

15 The same view is expressed by GROBHANS, A. - LANDI, N. Arbitration Agreements: Written Form Requirements and New Means of Communication. Bocconi Legal Papers, 2014, 4, p. 226.

16 See the last paragraph of the Recommendation.

17 See UNCITRAL 2005, supra note 9, at 20.

18 For a comprehensive overview see GROBHANS, op. cit., pp. 228-231. One can also add Czech arbitration law to this list, as described below in note 38 .

19 According to the NYC Guide, p. 51, since the Recommendation's adoption, national courts have more consistently enforced arbitration agreements pursuant to the less stringent formal requirements available under their national laws or treaties. 
survey of all relevant decisions on various aspects of the writing requirement, but only a simplified overview of selected judgments closely related to the central theme of this paper.

\subsection{PRE-RECOMMENDATION PRACTICE}

Only one reported decision from the pre-Recommendation times deals directly with the issue of arbitration agreement contained in an exchange of emails. It is the (in)famous Halogaland (Norway) Court of Appeal decision of $1999,{ }^{20}$ in which the court held that a contract (for the fixture of a vessel for the carriage of 3,500 m.t. of herring) concluded by an exchange of emails by reference to the GENCON charter party did not constitute an arbitration agreement in writing. The court held that the basic requirements of legal protection set up by the Convention were not met. ${ }^{21}$

Other courts seemed to be less formalistic, even though the decisions concerned other new means of communication (not listed in the Convention) than email. Most of the courts considered telexes and (tele)faxes as meeting the form requirement of the Convention. ${ }^{22}$ One Swiss court stated that, in the light of modern means of communication, unsigned writings play an increasingly important role and signature requirements are less important. ${ }^{23}$ It also confirmed that when the arbitration agreement is contained in an exchange of documents, the signature requirement does not apply. ${ }^{24}$ Another Swiss court held that it suffices that the agreement be contained in a document allowing for written proof and confirmation of the common intent of the parties. ${ }^{25}$

\subsection{POST-RECOMMENDATION PRACTICE}

The reported decisions issued after the Recommendation show almost an unanimous support for the conclusion that an arbitration agreement contained in an exchange of emails without (qualified) electronic signature(s) still qualifies as formally valid under Art. II(2) of the Convention.

There are two decisions of the Federal Court of Australia from 2006 and 2007, respectively, showing that the court had no doubts whatsoever that emails are included in Art. II(2) of the Convention. In the first case, Comandante Marine Corp v Pan Australia

20 Halogaland Court of Appeal, 16 August 1999, cited in UNCITRAL 2005, supra note 9, at 7 n. 20.

21 For a more detailed account of the case see LANDAU, supra note 6, pp. 210-211.

22 See UNCITRAL 2005, supra note 9, at $14 \mathrm{nn}$. 52-53 with examples from Germany, USA, Switzerland, France, Austria or Italy. See also Manitoba Court of Appeal in Proctor v Schellenberg [2003] 2 WWR 621 at 628.

23 Case Compagnie de Navigation de Transports SA v. MSC Mediterranean Shipping Company SA (1995) BGE 121 III 38. See UNCITRAL 2005, supra note 9, at 15 n. 56. The decision is criticized in UZELAC, A. The Form of the Arbitration Agreement and the Fiction of Written Orality. How Far Should We Go? Croatian Arbitration Yearbook, 2001, 8, pp. 87-88.

24 See Compagnie, cited supra note 23. See also Tradax Export SA v. Amoco Iran Oil Company, Federal Tribunal, Switzerland, 7 February 1984. See NYC Guide, supra note 10, at 56.

25 Court of Appeal in Basel, DIETF Ltd v RF AG (1994). See United Nations, supra note 10, p. 14 n. 55. 
Shipping Pty Ltd, ${ }^{26}$ the court cited with approval the Canadian case Proctor $v$ Schellenberg, ${ }^{27}$ emphasizing that " $[\mathrm{w}]$ hat is important is that there be a record to evidence the agreement of the parties to resolve the dispute by an arbitral process. This flexibility is important in this day and age of changing methods of communication". ${ }^{28}$ The second decision only cited the Comandante case with approval. ${ }^{29}$

Other courts followed the Australian suit. In the US case Glencore Ltd. v. Degussa ${ }^{30}$ the court concluded that a sales contract contained in an exchange of emails and incorporating an arbitration agreement by reference meets the writing requirement and even the parties did not dispute that email communications qualify as "letters and telegrams" within the meaning of the Convention. ${ }^{31}$ Also, there are at least two cases from the Indian Supreme Court where it did not hesitate to find that the arbitration agreement contained in an exchange of emails was valid, even though the contract itself may have been incomplete. ${ }^{32}$ A 2012 Spanish decision held that the list of documents set out in Article II is not exhaustive and therefore an arbitration agreement concluded by electronic means of communication fulfils the writing requirement. ${ }^{33}$ Finally, there is also a decision of the Greek court in Piraeus, which the Czech Supreme Court mistook for a US decision (see in part 4 below). ${ }^{34}$ The Greek court held that an exchange of letters, which fulfils the writing requirement under Article II(2) of the Convention, also includes an exchange of emails, as under the applicable rules on evidence of the Greek Civil Procedure Code, an email is by its nature equated to a document such as a letter. ${ }^{35}$

It seems that the only "outlier" in the post-Recommendation practice is a Brazilian court, which in 2007 denied recognition to an unsigned arbitration agreement that had been exchanged via telexes. ${ }^{36}$

Still, it is safe to say that the courts practice overwhelmingly shows that an exchange of emails meets the writing requirement of the Convention.

26 Comandante Marine Corp. v. Pan Australia Shipping Pty Ltd., 20 December 2006, [2006] FCAFC 192, available at: http://www8.austlii.edu.au/cgi-bin/viewdoc/au/cases/cth/FCAFC/2006/192.html.

27 Sheldon Proctor v. Leon Schellenberg, Court of Appeal of Manitoba, Canada, 11 December 2002.

28 See Comandante, para. 154.

29 APC Logistics Pty Ltd. v. CJ Nutracon Pty Ltd., 16 February 2007, [2007] FCA 136, at 4. The decision is available at: http://www8.austlii.edu.au/cgi-bin/viewdoc/au/cases/cth/FCA/2007/136.html.

30 Glencore Ltd. v. Degussa Engineered Carbons L.P., 24 January 2012, 2012 WL 223240 (S.D.N.Y.). The case is available at: https://cases.justia.com/federal/district-courts/new-york/nysdce/1:2011cv07153 /385995/48/0.pdf?ts $=1411558949$.

31 See Glencore, at 42 n. 27.

32 See Shakti Bhog Foods Limited vs. Kola Shipping Limited, (2009) 2 SCC 134, available at: https://indiankanoon.org/doc/1911324/, or Trimex International FZE Ltd. v. Vedanta Aluminium Ltd., (2010) 3 SCC 1, available at: https://indiankanoon.org/doc/658803/.

33 High Court of Justice of Cataluña, 15 March 2012, RJ 2012/6120. See NYC Guide, supra note 10 , at 56 n. 270 .

34 Piraeus Single-Member First-Instance Court Judgment 2150/2017 (Admiralty Division).

35 See the comment cited in note 52.

36 Oleaginosa Moreno Hermanos Sociedad Anónima Comercial Industrial Financeira Imobiliaria y Agropecuaria v. Moinho Paulista Ltda., Superior Court of Justice, Brazil, 7 March 2007, Motion for Clarification on SEC 866. See NYC Guide, supra note 10, at 57 n. 275. 


\section{CZECH APPROACH TO THE ISSUE - ZEVETA LITIGATION}

\subsection{CZECH PRACTICE UP TO ZEVETA}

Interestingly there are no reported Czech decisions on the issue. The author cannot exclude that there are some unreported lower court cases, but what we can say with the utmost certainty is that the issue has never reached the Czech Supreme Court. This only happened in the case which we dub ZEVETA (the name of the claimant), which was decided on May 16, $2019^{37}$ and which is analysed further below in parts 5.2 and 5.3.

Also, Czech doctrinal writings (to the best of the author's knowledge) have not addressed the issue directly. They rather commented on the domestic law on arbitration, ${ }^{38}$ whose section 3 para. 1 stipulates that the written form is preserved, if the arbitration agreement is concluded by telegraph, telex, or electronic means that provides a record of the content and identification of parties to the agreement. There is a unanimous opinion that email communication is covered by this provision, ${ }^{39}$ but according to some authors there might be instances, where a qualified electronic signature will be necessary to preserve the validity of the agreement. ${ }^{40}$

Thus, in ZEVETA the Supreme Court faced an issue on which the Czech practice to date was of little assistance, if any.

\subsection{ZEVETA LITIGATION: FACTS OF THE CASE AND LOWER COURTS' OPINION}

The ZEVETA dispute arose out of the contract between a Czech company called ZEVETA Bojkovice (the claimant) and a Spanish company FAGOR ARRASATE $\mathrm{S}$. COOP (the defendant). It is not quite clear from the decision what the exact subject matter of the contract was, except that it was some kind of a contract for work ("smlouva o dílo" in Czech, "der Werkvertrag" in German). In any event, it was undisputed that there had been an exchange of the draft contract between the parties via emails. The defendant sent the draft contract (without any signature) as an attachment to an email, in which it asked the claimant to send it back signed and stamped. Five days later the claimant sent the contract back via email, together with a proforma invoice. The contract contained in its Art. 11 an arbitration clause, which read "all disputes, which may arise and cannot be settled amicably, will be submitted to a court of arbitration and settled according to European principles laid down for this field." 41 It is quite obvious at first glance that the arbitration clause is very poorly drafted and that it would require

37 Decision of the Supreme Court of the Czech Republic dated 16. 5. 2019 No. 23 Cdo 3439/2018.

38 Act No. 216/1994 Coll., on arbitration and enforcement of arbitral awards, as amended.

39 See PFEIFFER, M. - PAUKNEROVÁ, M. - RŮŽIČKA, K. et al. Mezinárodní obchodní právo. 1. vyd. Plzeň: Aleš Čeněk, 2019, p. 315.

40 See BĚLOHLÁVEK, A. J. Zákon o rozhodčím řizeni a o výkonu rozhodčích nálezů. Komentár̆. 2. vyd. Praha: C. H. Beck, 2012, marg. 03.29 ff.

41 It is the author's working translation of the Czech version, which reads "všechny spory, které by mohly vzniknout, a nebude je možné řešit smírně, budou postoupeny rozhodčímu soudu a řešeny podle evropských zásad stanovených pro tuto oblast". 
considerable effort to figure out, which court of arbitration (probably an ad hoc tribunal or an ad hoc arbitrator?) and under which "European principles" should conduct the arbitration. It could have been a reason why the claimant tried to avoid this clause by bringing a claim before Czech courts (in that particular case to the District court in Ostrava) instead of pursuing the arbitration. However, the defendant opposed this move by contesting the court's jurisdiction, claiming that there is a valid arbitration clause.

Both the first instance court and the appellate court (the Regional Court in Ostrava) dismissed the action in favour of arbitration, holding that the clause is valid under the Czech law on arbitration ${ }^{42}$ and the European Convention on International Commercial Arbitration of 1961 (the "Geneva Convention"). ${ }^{43}$ The appellate court noted that the fact that electronic communication is not explicitly mentioned in the Geneva Convention does not mean that it is excluded, but only that it was not a usual means of communication at the time of the drafting of the convention. The court also took into account the fact that the content of the contract was not disputed between the parties; the claimant only objected that given the lack of the defendant's signature the contract was concluded only orally. It rejected the claimant's argument that the clause was invalid also because of its ambiguity, including its silence on how to constitute the tribunal. In this respect the court referred to Art. 4(3) of the Geneva Convention, from which it follows that if the arbitral clause contains no indication regarding the organization of the arbitration there are steps to be taken to resolve this. ${ }^{44}$ As the clause is not even clear on whether there should be a sole arbitrator or more arbitrators, the court's conclusion might seem doubtful. However, as the ambiguity of the clause at hand is not central to the theme of this article and it did not come up again in the ensuing Supreme Court litigation (the claimant did not raise it for some reason), we will leave it aside without delving into any more details on this issue.

The claimant filed an extraordinary appeal (“dovolání" in Czech) to the Supreme Court (the "Court") claiming that the lower courts' opinion is at odds with the Court's case-law on written form requirements in electronic communication. It cited three Supreme Court cases, all related to purely internal relationships (without an international element) governed solely by Czech law, in which the Court, unfortunately, ${ }^{45}$ required that the so-called qualified electronic signature be attached for the written form to be preserved in case of emails (electronic communication); "simple" emails were not sufficient. ${ }^{46}$

42 See above, part 4.1 and note 38 .

43 See its Art. 1 para. 2 letter a) reading “the term: 'arbitration agreement' shall mean either an arbitral clause in a contract or an arbitration agreement, the contract or arbitration agreement being signed by the parties, or contained in an exchange of letters, telegrams, or in a communication by teleprinter and, in relations between States whose laws do not require that an arbitration agreement be made in writing, any arbitration agreement concluded in the form authorized by these laws".

44 See Art. 4(3) of the Geneva Convention.

45 In the author's opinion, these domestic cases have been wrongly decided on this point, but this goes well beyond the scope of this article.

46 See Judgment of the Supreme Court of the Czech Republic dated 30. 10. 2009 No. 33 Cdo 3210/2007, Judgment of the Supreme Court of the Czech Republic dated 4. 9. 2013 No. 21 Cdo 3693/2012 or Decision of the Supreme Court of the Czech Republic dated 1. 6. 2017 No. 20 Cdo 1741/2017. 
The Court first distinguished the issue in question from the case-law relied upon by the claimant, stating that these cases related to purely domestic matters, while in this case it was a question of the formal validity of an arbitral clause concluded between entities from different states contained in an exchange of emails without a qualified electronic signature. Thus, in the Court's view it was a new question, as yet unsettled in its case-law. Moreover, it was a question of international trade reaching beyond Czech borders.

The Court then went on to determine, which law was applicable to this question. It first refused the application of the Czech-Spanish treaty on judicial cooperation of $1987,{ }^{47}$ as it contains a conflict-of-law rule for arbitral agreements validity only at the arbitral award enforcement stage.

The Court then shifted its attention to the Geneva Convention and the New York Convention. The Court first noted that neither of the conventions specifically address their mutual relationship. In such a case it was necessary, in the view of the Court, to find out, whether the later adopted (being in effect) convention would (and to what extent) supersede the older one (based on the principle of lex posterior derogat legi priori) ${ }^{48}$ or whether it should apply the convention which enables reaching (its) goal more easily and efficiently. The Court stated that between the Czech Republic and Spain the older convention is the Geneva Convention, as Spain ratified first the Geneva Convention (in 1975) and only later (in 1977) the New York Convention. The latter is thus lex posterior. Also, given the New York Convention's higher number of signatory states and more case-law interpreting its text, the Court concluded that it was also more efficient for the resolution of the question at stake. However, the Court did not stop there and kept looking for further evidence to support its conclusion that the New York Convention should be applicable in this situation. The Court observed that the Geneva Convention has fewer signatory states but found no evidence that this convention should among them prevail over the New York Convention. On the other hand, the Court opined that the New York is lex specialis, as it contains the direct substantive rule on the question of the form of the arbitration agreement, while the Geneva Convention contains only a conflict-of-laws rule. This finding is quite surprising, as both texts are very similar and both read more like a substantive rule on form than a conflict rule. Unfortunately, the Court offered no reasons for this conclusion. Be that as it may, given the similarity of both texts (which the Court also explicitly acknowledged), the Court would probably have reached the same conclusion on the issue of form, regardless of which convention it interpreted. In any event, for the above reasons the Court applied the New York Convention.

47 Agreement concerning judicial assistance and recognition and enforcement of judgments in civil matters, done in Madrid, 4 May 1987. Treaty Series. Treaties and international agreements registered or filed and recorded with the Secretariat of the United Nations. Volume 1524. [online]. Accessed [April 12, 2020] at https://treaties.un.org/doc/Publication/UNTS/Volume\%201524/v1524.pdf.

48 This is basically the rule contained in Art. 30 para. 3 of the Vienna Convention on the Law of Treaties of 1969 , but the Court did not specifically cite it, even though this convention should provide a primary tool for resolving conflicts of international treaties. 
When applying the New York Convention, the Court rather quickly arrived at the conclusion that the list of forms contained in Art. II para. 2 of the Convention is not exhaustive. The Court cited with approval the Recommendation and also the International Council for Commercial Arbitration, which reached the same conclusion. ${ }^{49}$ It also referred to two decisions of foreign courts that were of the same view. The first one was the Indian Supreme Court case Great Offshore Ltd. v. Iranian Offshore Engineering. ${ }^{50}$ It is to be noted that this decision is concerned with the exchange of faxes rather than emails, but, admittedly, the rationale is the same. ${ }^{51}$ The second case was the "Piraeus Single_Member First-Instance Court No. 2150/2017" case, which the Court identified as a "lower US court decision". However, at first glance this does not sound right, as the name of the court does not resemble any US court and Piraeus is a port city in Greece. Upon closer inspection, the author found out that the citation did indeed relate to a Greek court (admiralty division) decision on the issue. ${ }^{52}$ Mistaking a Greek decision for a US one is a surprising oversight at a supreme court level, but it has in principle no bearing on the rationale of the Court's reasoning. As described in part 4.2, it is true that there are quite a few foreign courts' decisions following the logic of the Recommendation. The Court thus followed an expected path.

To further support this conclusion, the Court recalled that in the recent past it had made the same findings when it came to the CISG. In its decision No. 23 Cdo 1308/2011 of 17 December 2013, it construed Art. 13 of the CISG $^{53}$ in a way that the written form includes not only the telegram and telex explicitly mentioned by the convention, but also other forms of (electronic) communication, including email.

However, the Court's conclusion that an email belongs among the acceptable forms pursuant to Art. II(2) of the Convention does not dispose of the entire matter. The Court still faced the essential question as to whether it suffices for the form to be preserved to have a simple (plain) email without any qualified electronic signature. As we have seen above, in the domestic disputes the Court has held a rather formalistic view requiring a qualified electronic signature for the written form to be valid. Fortunately, the Court has proven to be less formalistic when it comes to the international arena.

First, the Court emphasized that the Convention permits an exchange of telegrams, which also do not contain any (qualified) signatures. Secondly, it referred to other signatory states courts' decisions which held that no signatures are necessary when it comes

49 Unfortunately, it is not clear, which exact publication was cited by the Court, as the full citation is missing in the judgment (probably by omission).

50 Decision of August 25, 2008. Available at: https://indiankanoon.org/doc/123878146/, also annotated at http://newyorkconvention1958.org/index.php?lvl=notice_display\&id=1392. Accessed [April 12, 2020].

51 The Supreme Court probably carried over slightly misleading description of the case as "an exchange by e-mails with a confirmation by fax" from the NYC Guide, supra note 10, at 55 n. 266. Available at: http:// newyorkconvention1958.org/index.php?lvl=cmspage\&pageid=10\&menu=618\&opac_view=-1\#50.

52 It seems that the Czech Supreme Court's source was an article by Antonios D. Tsavdaridis of 19 October 2017 called "Form and proof of arbitration agreements incorporated by reference under New York Convention", published by International Law Office and available at ROKAS law firm website: https:// www.rokas.com/uploads/Form_and_proof_of_arbitration_agreements_incorporated_by_reference under_New_York_Convention.p̄pdf. Accessed [Āpril 12, 2020].

53 United Nations Convention on Contracts for the International Sale of Goods, done in New York, 11 April 1980. UNTC. United Nations Treaty Collection. [online]. Accessed [October 13, 2019] at: https://treaties .un.org/pages/ViewDetails.aspx?src=IND\&mtdsg_no=X-10\&chapter=10\&lang=en. 
to the "exchange" of documents under Art. II para. 2 of the Convention. ${ }^{54}$ The Court also cited, in support, the EU E-Commerce Directive of 2000, ${ }^{55}$ which requires that the (EU States) national "legislation does not hamper the use of out-of-court schemes, available under national law, for dispute settlement, including appropriate electronic means". ${ }^{56}$ For the sake of completeness, the Court, in the very end of the decision, recalled its judgment on another international treaty, the CMR of $1956 .{ }^{57}$ In that decision, ${ }^{58}$ handed down by the Court's grand chamber, the Court stated that a "written claim" under Art. 32 para. 2 of the CMR Convention includes also email communication without a qualified electronic signature. The grand chamber arrived at that conclusion after a thorough comparative analysis of several sources and foreign courts' decisions (including the Supreme Courts of Austria, Germany, and the Netherlands).

Based on the above, the Court concluded that the requirement of a qualified electronic signature would be excessive and in breach of Art. II of the New York Convention, which does not require (any) signature when it comes to the arbitration agreement contained in an exchange of (any) documents. ${ }^{59}$

\section{CONCLUSIONS}

Arbitration is one of the favourite dispute resolution mechanisms in international commerce. The New York Convention provides the wide-spread framework for enforcing arbitration agreements and arbitral awards around the globe. Its provision on the formal validity of arbitration agreements has undoubtedly been far outgrown by the advance of technologies and an overall switch to electronic forms of communication. Yet, the majority of States' courts have been able to adapt the Convention's interpretation to the needs of the modern era, holding that an exchange of emails (without signatures) lends to a valid arbitration agreement. This majority view was further advanced by the 2006 UNICTRAL Recommendation that construed the list of forms in Art. II(2) of the Convention as inclusive, not exhaustive.

The Czech Supreme Court followed this majority opinion, when the Court encountered the issue in its 2019 ZEVETA decision. Despite its some rather formalistic decisions on purely domestic disputes, requiring qualified electronic signatures for emails to be considered a written form, the Court looked for an autonomous interpretation of the Convention and other States case-law to deviate from its domestic approach.

54 The Court explicitly cited decision Compagnie and the NYC Guide, supra note 10, at 56-57.

55 Directive 2000/31/EC of the European Parliament and of the Council of 8 June 2000 on certain legal aspects of information society services, in particular electronic commerce, in the Internal Market ('Directive on electronic commerce'). Official Journal of the European Union, L 178. 8. 6. 2000

56 See Art. 17 of the E-Commerce Directive.

57 Convention on the Contract for the International Carriage of Goods by Road, done in Geneva, 19 May 1956. UNTC. United Nations Treaty Collection. [online]. Accessed [April 12, 2020] at: https://treaties .un.org/Pages/ViewDetails.aspx?src=TREATY\&mtdsg_no=XI-B-11\&chapter=11\&clang=_en.

58 See Decision of the Supreme Court of the Czech Republic, dated 15. 11. 2016, No. 31 Cdo 1570/2015.

59 As the Court apparently based its view and conclusions on the international character and autonomous interpretation of the Convention, it is questionable as to whether it would be willing to transpose this approach also into a purely domestic arbitration setting (however commendable that might be). 
The Court thus confirmed that an exchange of emails, even without signatures, meets the writing requirement of the Convention. The decision is to be welcomed for being attentive to the reality of international commerce and further supporting international commercial arbitration in the Czech Republic. ${ }^{60}$

JUDr. Petr Bř́za, LL.M., Ph.D.

Faculty of Law, Charles University, Prague

brizap@prf.cuni.cz

60 Another past example of the Supreme Court's rather positive attitude to international commercial arbitration is decision No. 23 Cdo 1034/2012, dated 30. 9. 2013, under which it is possible to submit a wholly domestic commercial case to international arbitration. On the other hand, one may also find other decisions that fit less within the needs of international commercial arbitration. 